宿題報告

食道アカラシアの病態と外科的治療

\author{
千葉大学第 2 外科 \\ 平嶋毅
}

\title{
STUDIES ON THE PATHOPHYSIOLOGY AND SURGICAL TREATMENT OF ESOPHAGEAL ACHALASIA
}

\section{Tsuyoshi HIRASHIMA}

Second Department of Surgery School of Medicine, Chiba University

1986年までの 41 年間に千葉大第 2 外科を訪れた食道アカラシフ 444 例（男200例，女 244 例）の病態を 食道 $\mathrm{X}$ 線, 内圧, 筋電図, 内視鏡および胃液検查で検討した。本症は内圧細分類による $\mathrm{A}_{1}, \mathrm{~A}_{2}, \mathrm{~A}_{3}$ 型のごとき初期像（食道緊張型）と B 型のごとき末期像（弛楥型）がある．本症に食道癌を合併した 18 例 $4.1 \%$ のち病悩期間 20 年以上の症例は 12 例であった。

外科治療を行った275例の遠隔追求245例中, 良好は165例, 軽快は43例と併せて $84.9 \%$ が改善された。 104例に施行された胃弁移植術の遠隔追求97例中, 良好91例, 軽快 6 例とすべて改善した. 教室で再手 術をした30例（教室13例，他施設17例）45件の $86.7 \%$ が通過障害を理由とした。再手術の方法は胃弁 移植術14例がいずれも好成績であった。

索引用語：食道アカラシア，食道緊張型，食道弛楥型，食道癌合併，胃弁移植術

緒言

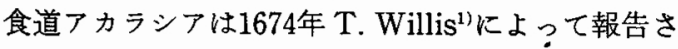
れたが，その成因，病態が複雑なため，その病名も噴 門㾏挛症, 特発性食道抎張症, あるいは噴門無弛緩症 などと呼ぱれてきた，歴史的に本症の成因，病態，診 断および治療について諸家により幾多の報告あるが， 著者も長年にわたり, 本症について基礎的，臨床的に 研究を続けてきた.

本稿においては千葉大第 2 外科を訪れた本症 444 例 を約40年間にわたる長期に観察した臨床像すなわら統 計, $\mathrm{X}$ 線検査, 食道内王測定, 筋電図, 内視像衫よび 胃液分泌態度からみた病態と教室で2)創案した胃弁移 植術と他術式の遠隔成績, 術後の病態, 再手術の面よ り検討し $2 ， 3$ の知見を得たので報告する。また本症の 病態に関連して合併頻度の高い食道癌についても述べ る.

* 第29回日消外会総会

<1987年 7 月 8 日受理>別刷請求先: 平嶋毅

干280 千葉市亥鼻 1-8-1 千葉大学医学部第 2

外科

\section{I. 病態に関する検討}

1. 統計的事項

まず統計事項について述べる，図 1 は1946年から 1986年交での 41 年間に千葉大第 2 外科（以下教室と略 す)の外来を訪れた食道アカラシア444例の年齢と性別 である. 年齡では男女とも30歳から39歳をピークとし て若年者から高龄者まで山なりの移行を示している. 男は総数で200例, 女は244例で男女比は 1 対1.2で女性 にやや多く，この傾向は諸家の報告と同じである，病 悩期間では, 1 年未満が 90 例 1 年以上 5 年末満が 157 例 で両者を併せると $5.7 \%$ と半数以上を占める. $5 \sim 9$ 年

図 1 年鉦と性別

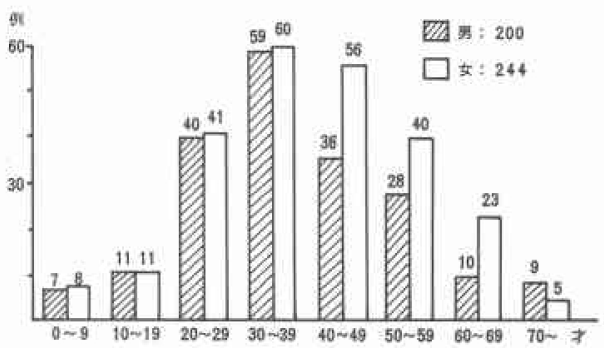


表 $1 \mathrm{X}$ 線拡張度と扗張型

\begin{tabular}{|c|c|c|c|c|}
\hline 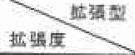 & Sp & $F$ & s & \\
\hline I & 71 制 & 8 & 0 & 79 \\
\hline II & 73 & 62 & 17 & 152 \\
\hline \multirow[t]{2}{*}{ III } & 7 & 23 & 21 & 51 \\
\hline & 151 & 93 & 38 & 282 \\
\hline
\end{tabular}

表 $2 \mathrm{X}$ 線抎張型と病悩期間

\begin{tabular}{|c|c|c|c|c|c|c|}
\hline and & -1 年 & $1 \sim 4$ & $5 \sim 9$ & $10 \sim 19$ & $20-$ & \\
\hline sp & 3791 & 66 & 23 & 14 & 11 & 151 \\
\hline$F$ & 19 & 38 & 18 & 14 & 8 & 93 \\
\hline \multirow[t]{2}{*}{ s } & 0 & 6 & 11 & 10 & 11 & 38 \\
\hline & 56 & 110 & 50 & 38 & 28 & 282 \\
\hline
\end{tabular}

は79例，10～19年は65例，20年以上は48例，不詳 5 例 となっている.

\section{2. 食道 $\mathrm{X}$ 線像よりみた病変の進行}

本症の病態を明暸に表わす食道 $\mathrm{X}$ 線像は食道疾患 研究会に拈いてすでにX 線払張型と抬張度が分類さ れている. 拡張型は下部食道の形態が $\mathrm{SP}$ 型, F 型, $\mathrm{S}$ 型に，また拉張度は最大横径によって I 度，II度，III 度と分けられている。表 1 は282例の X 線扗張型と払 張型の相関表である。抬張度が I, II, III度と高度と なるにつれ，拉張型も $\mathrm{Sp}, \mathrm{F}, \mathrm{S}$ 型と相関を示してい る. 表 2 によって X 線拡張型と病悩期間をみると Sp 型151例の 5ち半数以上の103例を 5 年未満が占めてお り, $\mathrm{F}$ 型93例の半数以上が 1 年以上 10 年末満となって 扣り両者は相関を示している。このように食道 X 線像 の拡張, 変形, 軸の屈曲などの推移は病悩期間と関連 がある言える. 食道最大横径を経時的に30例について 推移を観察したところ半数は短い年月に急に払張し残 りは長年月を経て除々に执張した。いずれにしても経 時的には病変が進行するるのと判断された。

3. 食道内圧変化よりみた内圧細分類

近年食道内纴測定法が確立されたことにより本症の 病態解明が進んだ訳である。図 2 は本症の食道静止圧 曲線を正常のそれと比較した図である，正常では左側 の呼吸相変換点 PRR を中心に部昇圧帯が形成され ており胸部食道では陰王となっているが，本症87例で
园 2 アカラシアの食道静此王曲線

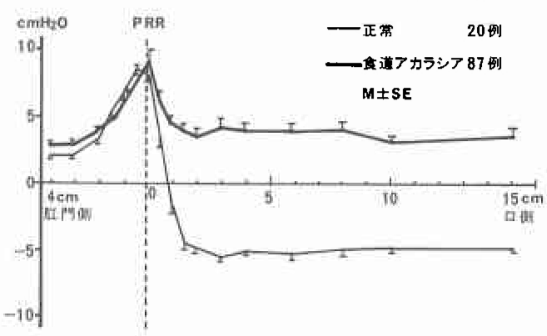

は食道静止圧は著明に上昇している。この静止圧の上 昇所見は通過障害の二次的所見である。

次に嗢下による内王変化をみると, 正常例の食道胃 接合部の内圧变化を 6 素子で記録してみると, 與下時, 下部昇圧帯の約 $3 \mathrm{~cm}$ の zone は陰性波が先行しついで 陽性波が後発する 2 相性波型を呈する，陰性波はこの 部位の弛緩機序を示す。一方本症に扣いては嚥下に よって正帯例のような陰性波が起こらない。このこと は本症の食道胃接合部の弛緩機序の欠如を意味するも ので通過障害をきたす重要な所見である．この陰性波 の出現しない $3 \mathrm{~cm}$ の zone は外科的侵襲を加克るに 当って必ず考慮すべき切開の範囲と考える.

踦下による内圧变化の陽性波の有無によって本症は $\mathrm{A}$ 型 B 型と分類 ${ }^{3}$ されている. 内圧分類によって本症 の食道静止圧曲線をみると $\mathrm{A}$ 型64例の平均曲線より B 型23例のそれがやや高く，通過障害が高度であると 考えられる.

内圧分類と X 線拡張型の関係を166例でみると内圧 分類が $\mathrm{A}$ 型, $\mathrm{B}$ 型となるに従って払張型も $\mathrm{Sp}, \mathrm{F}, \mathrm{S}$ 型と相関が明暸である(表 3 )。 また拡張度や病悩期間 ともほぼ同様な傾向を示している。

本症の内王変化をさらに詳細に検計したところ興味 あることに陽性波の出現する A 型には次の 3 群が細 分類された。すなわち $A_{1}$ 型は正常とは異なるが陽性波 に潜時のずれがあるすの， $\mathrm{A}_{2}$ 型は陽性波が同期して出 現するもの， $\mathrm{A}_{3}$ 型は陽性波が頻発するものである。図

表 3 内圧分類と $\mathrm{X}$ 線扗張型

\begin{tabular}{|c|c|c|c|c|}
\hline 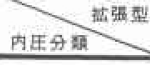 & Sp & $F$ & s & \\
\hline A & 749 & 31 & 9 & 114 \\
\hline \multirow[t]{2}{*}{ B } & 6 & 27 & 19 & 52 \\
\hline & 80 & 58 & 28 & 166 \\
\hline
\end{tabular}


図 3 食道アカラシアの内圧細分類

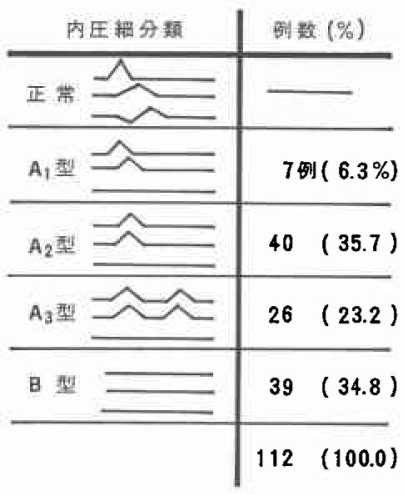

3 は本症112例の内圧細分類のシェーマとその例数で ある. $\mathrm{A}_{1}$ 型は 7 例と少ないが $\mathrm{A}_{2}$ 型は40例, $\mathrm{A}_{3}$ 型は26例 さらに B 型は39例となっついる。

内圧細分類と $\mathrm{X}$ 線扗張型の関連をみると $\mathrm{A}_{1}$ 型の 7 例全部が $\mathrm{Sp}$ であり，次いで $\mathrm{A}_{2}$ 型， $\mathrm{A}_{3}$ 型とななるにつ れて, F, S が見られ B 型になると $\mathrm{F}, \mathrm{S}$ が多くなって くる.

\section{4. 食道筋電図の発現様式}

$\mathrm{W}$ 型電極による管内誘導法食道笳電困による本症 の筋電図の発現様式は上, 中, 下部食道に燕下によっ て惹起される活動電位の発現様式によって 5 群に分け られた，正帯食道筋電図は，空嚥下後，上，中，下部 食道に一定の潜時をおいて活動電位が出現しており， 再現性のあるものである，本症のそれは，活動電位が 全域に発現するむの，同期性に発現，中部食道にて消 失, 中下部にて消失，扣よび全域にて消失するもので ある.これら 5 群の筋電圀の発現様式と X 線拡張型の 関連を27例について見たところ，活動電位がどのよう な形でも発現しているものは $\mathrm{Sp}$ 型, $\mathrm{F}$ 型に多い傾向 である.

食道筋電図と内圧波型の関連を見ると, 活動電位が 全域に発現，または同期性に発現している症例は，内 圧変化で陽性波の出現している $\mathrm{A}$ 型症例に多く, 活動 電位が，中，下部にて消失しているすのは内圧 B 型が 多い傾向である。このような食道筋電図の活動電位の 减弱, 伝達機序の障害は, 通過障害の第 2 の要因と考 えられる。

\section{5. 食道内視鏡所見記載基準の評価}

次に本症の食道内視鏡所見について述べる．表 4 は

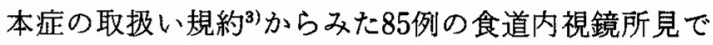
ある。本症85例のうち食道内腔払張の有るものが58例
表 4 取扱い規約からみた食道内視鏡所見

\begin{tabular}{|c|c|c|c|}
\hline 雨 & 胃 & ค1 $\mathrm{Ar}$ & $(\%)$ \\
\hline 到 & 基 所 & $580 \mathrm{AN}$ & $(682 \%)$ \\
\hline 苫 由 & 壁 曲 & 14 & $(16.5)$ \\
\hline \multirow{2}{*}{ 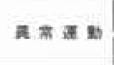 } & 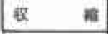 & 38 & (44.7) \\
\hline & 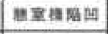 & 35 & $(41.2)$ \\
\hline \multirow{2}{*}{ 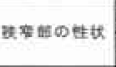 } & 速 端萑 & 85 & $(100,0)$ \\
\hline & 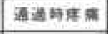 & 13 & $(15.3)$ \\
\hline \multirow{2}{*}{ 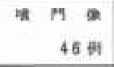 } & 表 & 22 & $(47.8)$ \\
\hline & めくんこみ & 20 & $(435)$ \\
\hline \multirow{2}{*}{ 粘 40} & \$ & 5 & $(71)$ \\
\hline & e & 20 & $(23.5)$ \\
\hline 弇垪: & ti in & 13 & $(15.3)$ \\
\hline
\end{tabular}

因 4 食道アカラシフの胃液分泌態度

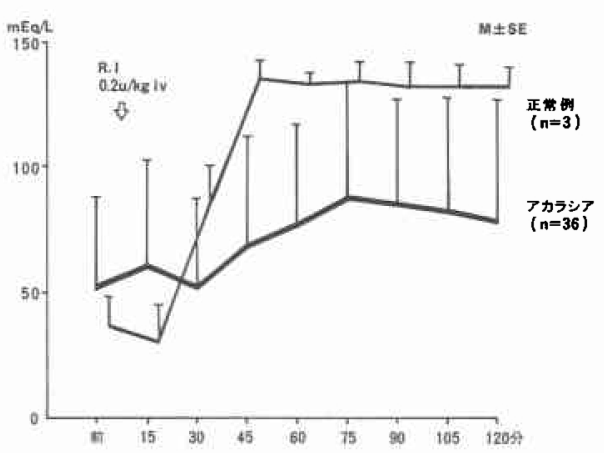

$68.2 \%$ ，異常収縮は 38 例に，悡室様樎凹は 35 例に認め られる，逆視よって噴門像を観察した46例中まきつき 22 例 $47.8 \%$ ，めくれこみ26例 $43.5 \%$ ぬ゙かが本症に多く 認められる所見である。

内視鏡的に本症を内腔払張の程度で分けてみると， 「なし」27例のうち Spが20例となっている。「軽度」38 例のうち $\mathrm{Sp} 23$ 例と，ともに Sp 型が多くみられ，一方 「高度」20例のらち F 8 例 S 9 例で F, S 型が多くなっ ている. 仮に本症を内視鏡によって程度分類するとし たら，この内空拡張「なし」「軽度」「高度」の表現が 妥当と思われる。

\section{6. 胃液分泌能度}

文献的にもほとんど報告のない本症の胃液分泌態度 について Hollander testを行いRoss \& Keyの基準 に従って判定した，図4 亿示すごとく本症36例の胃液 酸度は正常のそれに較べ低く, 本症は迷走神経系の障 害が深く関与していることが示唆される。ちなねに本 症36例のうち early positive (EP) 例は20例で, late positive (LP) 例は10例, さらに negative (N) 例は 6 例となっている. 胃液分泌能度と $\mathrm{X}$ 線拡張型の関連 をみるとまず20例の $\mathrm{EP}$ 症例中 $\mathrm{Sp}$ が14例を占め LP 
表 5 食道アカラシアの臨床像

\begin{tabular}{|c|c|c|c|c|c|}
\hline \multicolumn{2}{|l|}{ 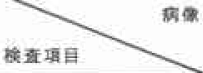 } & \multicolumn{2}{|c|}{$\begin{array}{c}\text { 初期 像 } \\
\text { (食這婜型） }\end{array}$} & \multicolumn{2}{|c|}{ 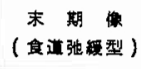 } \\
\hline 齿 筑 & 晴 & -1 年 & & 54 & 5 年 \\
\hline \multirow{2}{*}{ 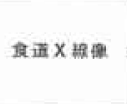 } & 非致都 & $\mathrm{sp}^{\text {型 }}$ & \multicolumn{2}{|c|}{$F$} & $\mathrm{~s}^{\text {整 }}$ \\
\hline & 怙造㾏 & $1^{\text {庶 }}$ & \multicolumn{2}{|c|}{ II $^{\text {鹿 }}$} & 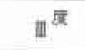 \\
\hline \multirow{3}{*}{ 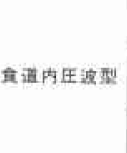 } & 4)正压 & \multicolumn{2}{|c|}{ 㡙度上是 } & \multicolumn{2}{|r|}{ 上开 } \\
\hline & 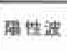 & \multicolumn{2}{|c|}{$A_{1}^{N}, A_{2}, A_{3}$} & \multicolumn{2}{|r|}{$B^{\text {整 }}$} \\
\hline & 路性诐 & \multicolumn{2}{|c|}{ 苒失 } & \multicolumn{2}{|c|}{ 献 } \\
\hline \multicolumn{2}{|c|}{ 食道筋電図活動奄位 } & \multicolumn{2}{|c|}{$\begin{array}{c}\text { 翼常または } \\
\text { 不规則出現 }\end{array}$} & \multicolumn{2}{|c|}{ 減退または消失 } \\
\hline 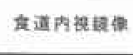 & 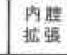 & to $\mathrm{L}$ & & & $\sqrt{12}$ \\
\hline \multicolumn{2}{|l|}{ 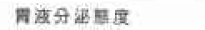 } & EP & \multicolumn{2}{|c|}{ LP } & $N$ \\
\hline
\end{tabular}

症例10例のちち $\mathrm{Sp}$ が 6 例, F が 3 例となっておう, N 症例では Sp 3 例, F 1 例，S 2 例となっている. 胃液 分泌態度についてはいまだ症例も少なく検討の予地は あるがやはり病変の進行と関連性はあるものと考学ら れる.

\section{7. 小括}

以上の諸検査によって本症の臨床像をたまとめたの が表 5 である. 本症は大別にして初期像と末期像に分 けられる．X 線的にみると病悩期間の長くなるにつれ て X 線像の経時的な推移があり病変は進行するるの と思われる。食道内圧波型から見ると初期像は陽性波 の多様に出現する $A_{1} A_{2} A_{3}$ 型のごとき食道の緊張型 で, 末期像は $\mathrm{B}$ 型で食道陽性波のない食道弛緩型であ る.

本症の病態ををとめると, 機能的な通過障害の本態 は接合部の開口機序の欠如で，これに食道の筋活動の 障害が加わったもので, 病変は進行性で初期像は食道 緊張がつよく，末期像は弛緩となる。この病態には迷 走神経系の障害が深く関与しているものと思われる.

\section{II. 食道癌の合併}

本症の病態に関連して比較的合併頻度の高に食道癌 について述べる。教室では本症444例のうち食道癌合併 例は18例 $4.1 \%$ であ.諸家の報告もほぼ同様といえる が食道疾患研究会全国集計は1388例中 49 例 $3.5 \%$ 之 なっており，いずれにしても本症に食道癌は高率に合 併するものとい克る。

症例を供覧する。症例は53歳の女性である。この症 例は1958年教室を訪れたとき食道 X 線像は $\mathrm{Sp}$ 型 I 度
因 5 病悩期間（食道アカラシアと食道癌合併例）

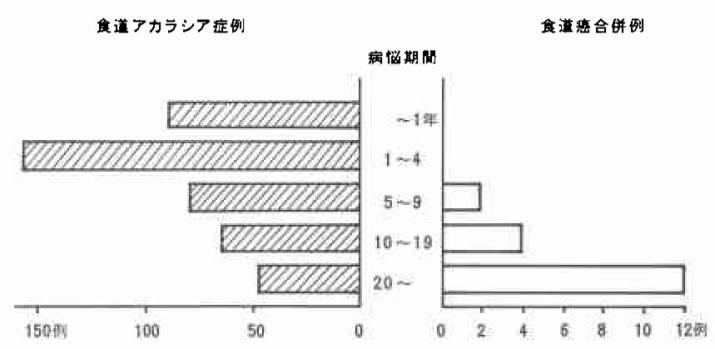

のアカラシアであったが，13年後の食道は $\mathrm{Sp}$ 型II度 と食道最大横径が拡張してきた，その後来院せず，約 10年後に燕下障害の増強, 背部痛, るいそらの症状で 来院したので X 線検查の結果, 食道癌取扱い規約 4 亿 よる IUIm に $11 \mathrm{~cm}$ に及ぶらせん深達型の食道癌の合 併が認められた。内視鏡でみると門歯列より $20 \mathrm{~cm}$ に 見党る陥凹明暸型の癌腫であり，まず合併療法として 放射治療を行ったところ，腫瘤は消退したので，次い で右開胸食道全摘術が行われた。切除標本は, 中, 下 部食道は著明に抗張して打り， 口側端に癌腫がある。

食道のアゥェルバッ八神経叢を組織像でみると变性 した壁在神経節細胞が認められ, 癌細胞の病理組織像 は放射線治療で崩壤壤死におちいった所見が認められ た.

図 5 は食道アカラシア症例を食道癌合併例との病悩 期間を比較したものである。食道癌合併例は病悩期間 が 5 年から 10 年末満で 2 例, 10 年から 20 年末満が 4 例, 20 年以上が12例となって招り病悩期間が延長するにつ れて，その発生頻度が高い傾向である。

前述した教室の18例の食道癌合併例のうち 4 例は他 施設で確認したものである。14例の教室で確認した症 例の癌腫の占居部位は上, 中部食道が 4 例, 中部食道 7 例，下部食道 3 例となっておう，上部㧍よび中部食 道に多く認められ，諸家の報告と同じ傾向である。

長さは $10 \mathrm{~cm}$ 以上の症例が 5 例もあり進行癌が多く なっている.

食道癌合併例の診断の時期であるが，14例のうち 6 例は初診時アカラシアと食道癌を同時に診断したもの で，8例はアカラシアの経過観察中食道癌を発見した あので，そのうち 6 例はアカラシアの手術後に経過を 観察中に発生をみている.

後者 8 例のうち 4 例は食道切除術を行い，3 例は放 射線治療を行っている．食道切除術を行った 6 例中 5 例は進行癌でいずれも 6 カ月以内に死亡し, 早期癌の 
1 例は経過観察中である.

これらのことにより, 本症に合併する食道癌は症状 が同じため早期発見しにくいことから, 病悩期間の長 い, とくに20年以上の症例には厳重な経過観察が必要 である。

\section{III. 外科的治療, とくに胃弁移植術の}

\section{遠隔成績と術後病態の検討}

本症に対する外科的治療として教室では1967年まで は裂孔拡大剝離術, 噴門成形術, 食道胃側々吻合術, 噴門切除術および粘膜外筋切開術を施行してきた。こ れ以降は粘膜外筋切開術と佐藤ら 移植術を施行してきた。

本項においては, 教室において行った各種の術式 275 例の遠隔成績と胃弁移植術を中心とした術後の病態に ついて検討した。

また再手術例からも各種術式を比較した。

1. 遠隔成績

表 6 は教室で初回手術を行ったすべての術式別遠隔 成績である．275例の手術例の遠隔を追求し党て245例 中, 良好は165例，軽快は43例で両者を合せると $84.9 \%$ の改善率になる。最も良い成績は胃弁移植術で104例の 5 ち追求 97 例では良好 91 例 $93.8 \%$, 軽快 6 例 $6.2 \%$ と $100 \%$ の改善率である.その他の術式では噴門切除術が $87 \%$, 噴門成形術, 食合胃側々吻合術, 粘膜外筋切開 術がおよそ75\%の改善率となっている。

遠隔時アンケートによって調べた術後「物がつかえ る感じ」は全体の追求204例のうち29例14.2\%となって いる。最も少ないのは胃弁移植術で2.1\%であり, 次い で粘膜外筋切開術の $18.8 \%$ などとなっている.

各術式と術後「胸のしみる, やける感じ」をみると 全体としては218例中 54 例 $24.8 \%$ である.最も少ないの が胃弁移植術で $16.8 \%$ ，次いで噴門成形術 $22.9 \%$ 粘膜 外筋切開術 $26.7 \%$ となっている.

表 6 遠隔成績

\begin{tabular}{|c|c|c|c|c|c|}
\hline 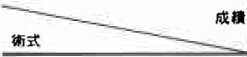 & 手玮数 & 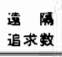 & 良好 & 䖵 & 不変 \\
\hline 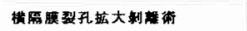 & 216 & 19 & $8(42.1 \%)$ & $3(15.8)$ & $8(42.1)$ \\
\hline 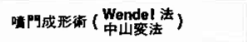 & 60 & 52 & $26(50.0)$ & $14(26.9)$ & $12(23.1)$ \\
\hline 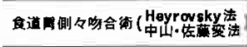 & 42 & 37 & $17(45.9)$ & $11(29.7)$ & $9(24.4)$ \\
\hline 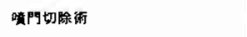 & 27 & 22 & $14(63.6)$ & $5(22.8)$ & $3(13.6)$ \\
\hline 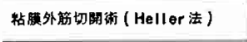 & 21 & 18 & $9(50.0)$ & $4(22.2)$ & $5(27.8)$ \\
\hline \multirow[t]{2}{*}{ 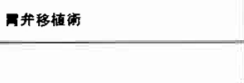 } & 104 & 97 & $91(93.8)$ & $6(6.2)$ & 0 \\
\hline & 275 & 245 & $165(67.3)$ & $43(17.6)$ & $37(15.1)$ \\
\hline
\end{tabular}

図 6 病悩期間と遠隔成績 その 1

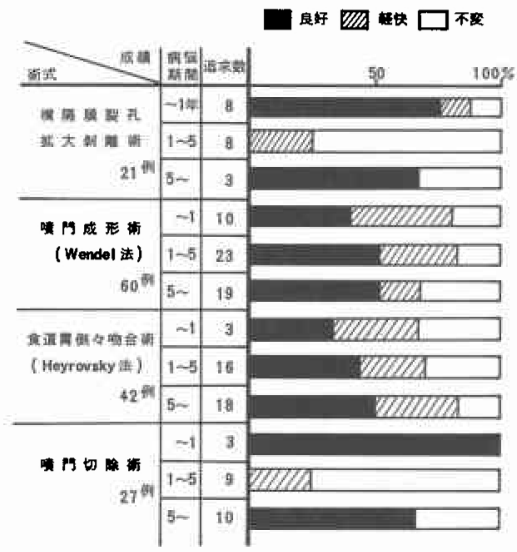

図 7 病悩期間と遠隔成績 その 2

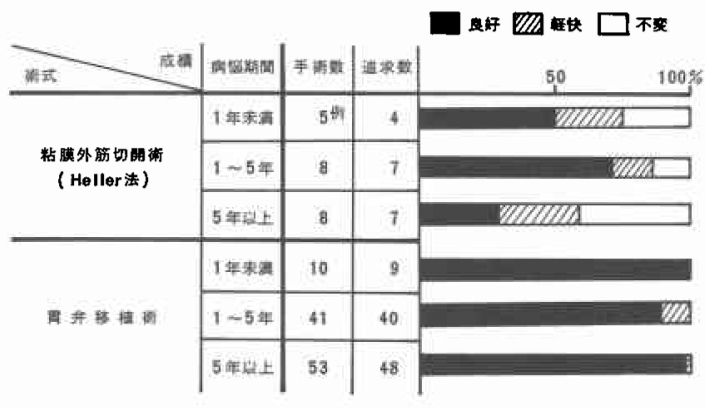

次に病悩期間と遠隔成績との関係を術式別に見ると 図6のごとく，まず裂孔拡大剥離術と噴門切除術は病 悩期間が 1 年末満で良好が多い，他の術式では病悩期 間による成績の差はない。

図 7 にると1965年以降に主として行われた粘膜外 筋切開術之胃弁移植術の成績を病脳期間でみると粘膜 外筋切開術は病悩期間 5 年以下では良好, 軽快が多く, 病悩期間が長いものは不変が多くなっている，一方胃 弁移植術はいずれの期間でも改善されている。

2. 胃弁移植術々後の病態

遠隔成績において他の術式と較べ好成績を得ている 胃弁移植術（以下本術式と略す）を中心として術後の 病態について述べる.

まず食道 X 線像についてであるが，本術式後の $\mathrm{X}$ 線像の経時的推移を検討した. 図 8 は払張度 I 度 II 度 の症例で本術式施行後 5 年以上を追求した 16 例の食道 最大横径の推移をみると術後 1 力月で最大横径は著明 に縮小し以後遠隔 5 年以上でもほとんどの変りはな い. 
図 8 I 度II 度症例の食道最大横径の推移

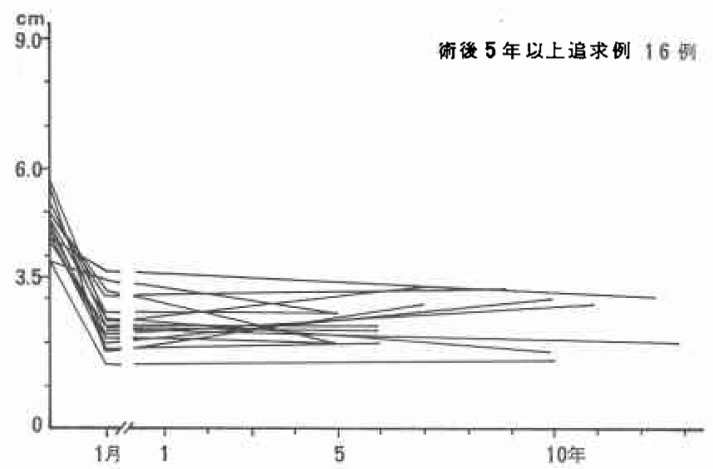

図 9 III度症例の食道最大横径の推移

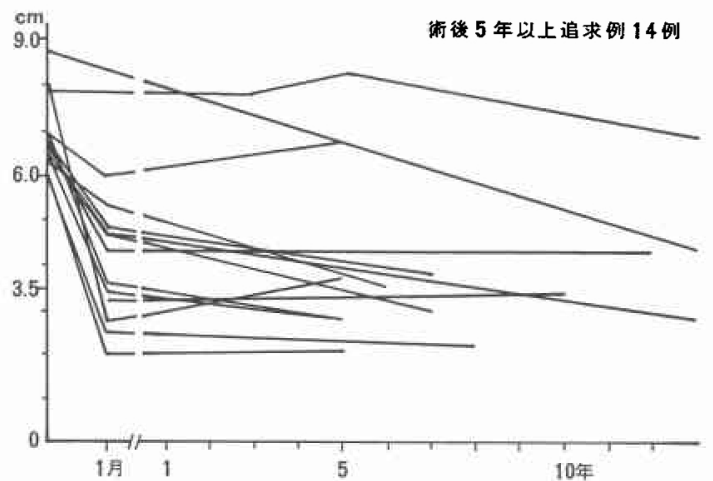

またIII度症例14例の食道最大横径の推移をみると図 9 のごとくで術後 1 力月で最大横径はほとんどの症例 で縮小し以下漸減する傾向をみせるが，そのうち2 例 は同じ大きさで推移している。

ちなみに X 線拡張型の代表例の術前後の所見を検 討する

症例 1 , 高 $\bigcirc$ 夕○；56歳の女性は1975年10月 $\mathrm{Sp}$ 型, II度, A 型, 病悩期間 4 年の症例であるが, 本術式施 行後11年の食道 X 線でバリウムの噴門通過は良好で かつ食道は細くなっている。

症例 2 , 中 $\mathrm{O}$ 能 $\mathrm{i} ; 34$ 歳の男性は1978年11月 F 型 II 度 B 型, 10 年の症例であったが, 本術式施行後 6 年で 食道 X線像では食道は細く噴門のバリウム通過は良 好である。

症例 3, 内○陽○；37歳の女性は1973年11月 $\mathrm{S}$ 型, III度, B 型, 10年の食道驰緩型の症例であったが，本 術式施行後11年の写真では食道の軸の屈曲も治ってい る.このよ5に本術式は拡張型のいかんを問わず食道 执よび噴門の所見は改善を示している。
困10 術前術後食道静止圧

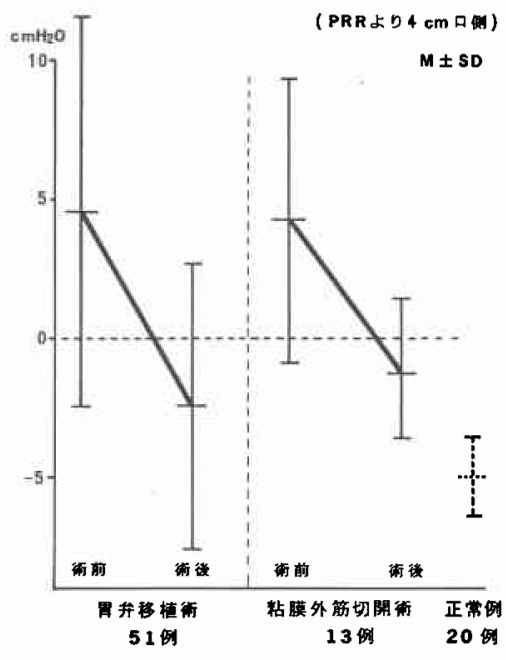

ただ最も病変が進行したと思われれる S 型III度の 症例は一部に軸の屈曲が残る症例が認められる.S III 症例14例についてこれを内圧分類 A 型 5 例, B 型 9 例 を別々に食道最大横経を経時的に測定した。これによ ると本術式を施行すると，A 型のほとんどの症例は最 大横経は早く縮小し軸の屈曲も直っている．B型では 横経の縮小もゆるやかでかつ軸の屈曲残存するのが多 い傾向であった，勿論両群とも噴門のバリウム通過は 良好であり，通過障害も改善している，以下それぞれ の実例について述べる。

症例 A，武O信；35歳の男性.この症例は1976年 S 型II度，A 型，17年であったが，本術式術後 1 年で噴 門通過良好食道は細くなり軸の屈曲は改善している。 7 年後になってもその所見はほとんど変っておらず, 愁訴もない。

症例 B，赤○友○；44歳の男性. この症例は1975年 12月, $\mathrm{S}$ 型亚度 B 型, 20 年であったが，本術式術後 6 年の食道 X 線像で噴門のバリウム通過は良好であっ たが，軸の屈曲は直っていない，しかし愁訴は無かっ た。この事は S IIIの B 型のごとく最も進行した症例は 食道の緊張が回復しにくい状態になっていることと考 壳られる。

次に食道内圧の面から検討した，図10は術前，術後 の食道静止王の推移である。本術式施行の 51 例, 粘膜 外筋切開術 13 例の PRR 上り $4 \mathrm{~cm}$ 口側に括ける静止圧 は前後においてとるに正常と較へ上昇しているが，術 後はいずれす低下し，陰圧となり，手術によって通過 改善がもたらされている。 
図11 胃弁移植術前後の内王細分類

\begin{tabular}{|c|c|c|c|}
\hline \multicolumn{2}{|c|}{ 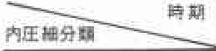 } & 洏 献 & \multirow{2}{*}{$\frac{\text { 䉼 }}{11(26.2)}$} \\
\hline$A_{1}$ 帮 & E & 2 制 $(4.8 \%)$ & \\
\hline $\mathrm{A}_{2}$ 型 & - & $19(45.2)$ & $19(45.2)$ \\
\hline $\mathrm{A}_{3}$ 型 & $\exists$ & $8 \quad(19.0)$ & $1(24)$ \\
\hline \multirow[t]{2}{*}{ B 些 } & $=$ & $13(31.0)$ & $11(26.2)$ \\
\hline & & $42(100)$ & $42(100)$ \\
\hline
\end{tabular}

次に内王変化についてみると，図11は本術式施行前 後の内圧細分類であるが，まず術前 $\mathrm{A}_{1}$ 型は 2 例 $\mathrm{A}_{2}$ 型 は19例， $\mathrm{A}_{3}$ 型は 8 例であったものが，術後はそれぞれ に11例, 19例， 1 例となり $\mathrm{A}_{1}$ 型が増え $\mathrm{A}_{3}$ 型が減ってい る.この事実は下部食道接合部における通過改善がも たらす陽性波すなわち蠕動波の回復，层達機序の回復 を意味するもので興味ある所見である。またこのよう な所見は粘膜外筋切開術など24例についても認められ ている.

その症例を呈示する。

症例 1，岡 $\bigcirc$ 重 $\bigcirc ； 37$ 歳の男性は術前 Sp 型 II 度, A 型， 5 年の症例であったが，空燕下によって食道各部 位に同期した陽性波が出現してたので細分類で $\mathrm{A}_{2}$ 型 とされていた。 この症例に本術式が施行されたところ, 食道 X 線像の改善之ともに燕下時陽性波は潜時をお いて出現し伝達機序の回復した $\mathrm{A}_{1}$ 型の所見を示した。 症例 2, 石○洋 $\bigcirc ： 42$ 歳の女性は術前 $\mathrm{S}$ 型III度, $\mathrm{A}$ 型， 2 年の症例であったが，燕下により同期した等高 性の低い陽性波が頻発して拈り $\mathrm{A}_{3}$ 型と考克られた。本 術式を施行後食道 X 線像の改善とともに讌下により 波高の異なった陽性波が潜時を掞いて出現し，伝達機 序の回復がうかがえたので $\mathrm{A}_{1}$ 型と判定した。

術後の逆流性食道炎を検討する目的で $\mathrm{pH}$ 引き抜き 曲線をみると，ず正常20例の平均曲線は胃内 $\mathrm{pH} 2$ か ら呼吸相変換点 PRRを含む下部昇圧带で急騰した口 側では pH 5 内至 6 となっている. 本術式術後は26例の 平均曲線で，ほ注正常之同様な曲線が得られており逆 流現象は認められない。また粘膜外筋切開術も淰洼同 じ形で移行している，その他の術式，すなわち噴門成 形術, 食道胃側々吻合術拉よび噴門切除術では正常曲 線とは異なった逆流現象を示す曲線となっていた。

本術式を施行した51例の術前術後の食道内視鏡所見 について述べる．本術式術後 1 力月の内視鏡所見であ るが，まず内腔拡張は術前の35例から術後19例へと，
表 7 教室初回手術例の術式別再手術率

\begin{tabular}{|c|c|c|c|}
\hline M的 & 手消列数 & 再手雨醉照 & 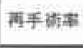 \\
\hline 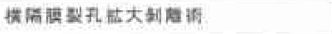 & 21 训 & $7(3)$ & $33.3 \%$ \\
\hline 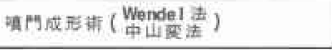 & 60 & $8(4)$ & 13.3 \\
\hline 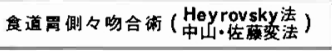 & 42 & $7(4)$ & 16.6 \\
\hline 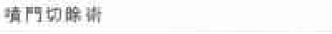 & 27 & 1 & 3.7 \\
\hline 站膜外筋切開術（Heller 法） & 21 & $3(2)$ & 14.2 \\
\hline \multirow[t]{2}{*}{ 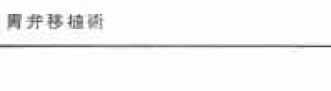 } & 104 & 0 & 0 \\
\hline & 275 & $26(13)$ & 9.4 \\
\hline
\end{tabular}

（）教室て再手術施行

また毠室様陥凹は20例から 3 例へと，また噴門像での まきつき，めくれこみは全例消失している。

粘膜肥厚はとれているようであるが, 術後 1 力月の 観察のためか，いまだ一部残存している所見もある。

胃液分泌態度についても検討だが，本術式施行 9 例 の術前, 術後の平均曲線は洼とんど变わりなく,この 事実は手技上，迷走神経は温存されていることを示す ものである.

以上の遠隔成績, 術後の病態よりみて胃弁移植術は 初期像, 末期像々もに通過改善に有効であり, 逆流防 止機構も温存された術式と考学られる。また初期像を 示寸症例には粘膜外筋切開術も有効であると考完られ る.

\section{3. 再手術からみた術式の評価}

本症の外科的治療上, 再手術症例に遭遇することが あり, 再手術の面からる, 術式の評価が可能である.

表 7 は教室で初回手術を行った275例の術式別再手 術率である。フンケートで判明した他施設で行われた ものむ含め 26 例 $9.4 \%$ に再手術が施行されている。最も 再手術率が高いのが裂孔拡大剥離術 $33.3 \%$ であり, 次 いで食道胃側々吻合術 $16.6 \%$, 粘膜外筇切開術 $14.2 \%$, 噴門成形術 $13.3 \%$ である，胃弁移植術症例には再手術 例はない。

教室で再手術を行った症例は 30 例であるが，初回手 術を教室で行ったもの13例，他施設で行ったもの17例 である，主なる術式を挙げると，裂孔拡大剥離術，噴 門成形術，粘膜外筇切開術がそれぞれ 6 例めり，食道 胃側々吻合術 4 例などである。裂孔抁大䟝離術，噴門 成形術は始めから下部食道接合部の十分な開大が得ら れなかったため，食道胃側々吻合術は主に逆流性食道 炎の愁訴のため, 粘膜外筋切開術は瘢痕性狭窄による ものであり，他施設で初回手術として胃弁移植術を 
因12最終手術が胃弁移植術症例の成績

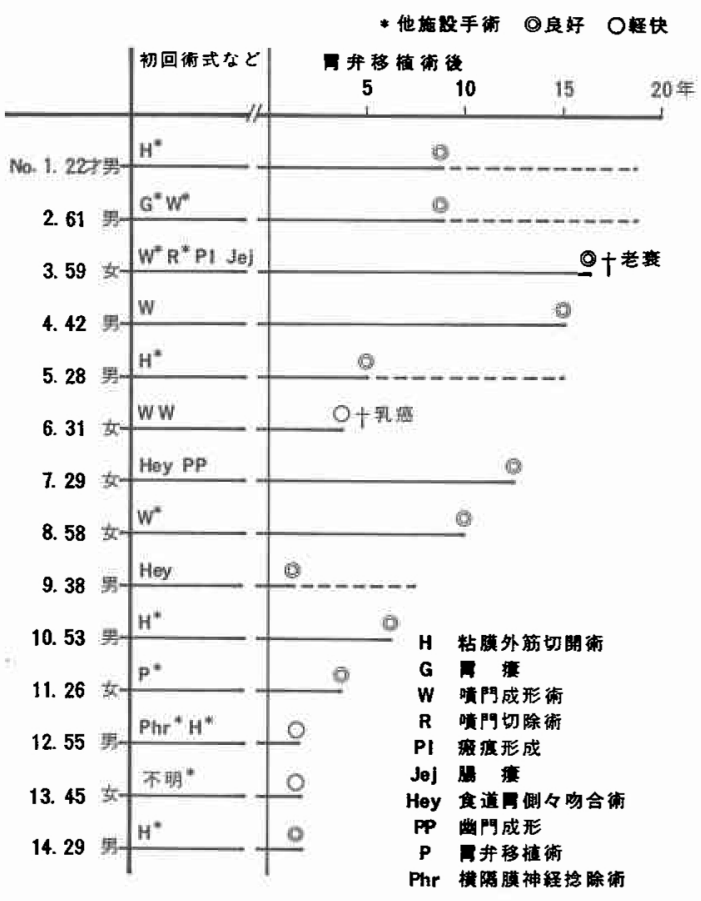

行った 1 例が教室で再手術を施行されたが，これには 胃弁が十分切開された下部食道に插入されていなかっ たものである。

教室で行った再手術の手術理由であるが30例 45 件の 再手術に括いて 2 回目手術以後の再手術理由の $86.7 \%$ は通過障害によるものであった。胸やけ，逆流による ものは8.9\%であった。

それでは再手術の方法としてどのような術式が施行 されたかをみると，まず比較的多く行われた食道胃 側々吻合術 8 例では 2 例の不变例があり, 噴門切除術 は 6 例行い 1 例手術死亡, 1 例不変という結果であっ た. 最も多く行ったのが胃弁移植術で14例行いすべて 改善している。

最終手術が胃弁移植術でそれ以降経過をみたのが図 12である。14症例とも良好または軽快となっている。 ちなみに 2,3 はの症例を報告する。

症例 No. 3 は59歳の女性であるが，他施設で初回噴 門成形術をついで噴門切除術を行い術後狭窄で当科隹 来院したものである. 教室では狭窄部成形術を行った がらまくいかず，残胃を利用して胸の中で胃弁移植術 を行ったところ，通過良好となった。

症例 No. 7 は29歳の女性で, 初回手術を食道胃側に
表 8 術式の適応

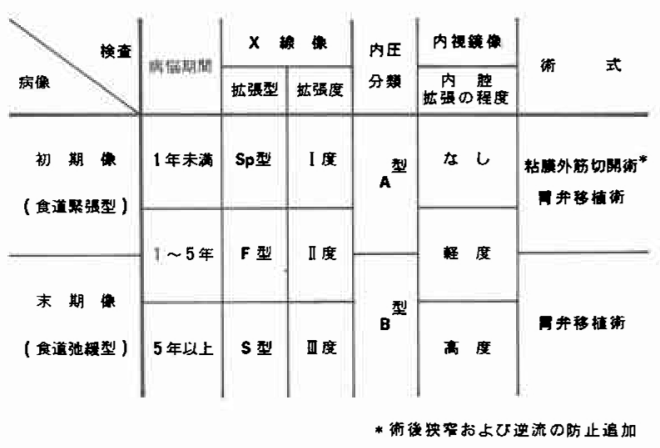

吻合術を行って11年目の食道 X 線像でみると, バリウ ムは噴門部を通過せず, 新らしく作った食道胃吻合部 からの逆流がつよく, 胸やけの愁訴が続き内視鏡的に 高度の食道炎が認められたため胃弁移植術を行った。 術後はX 線的に元の下部食道噴門部を通過しており, 愁訴もなく経過良好となった。

症例 No. 14 は29歳の男性で, 他施設で粘膜外筋切開 術を施行し 1 年 9 力月の食道 $\mathrm{X}$ 線像で噴門の通過障 害像が認められ, 愁訴す増強したので再手術として開 腹したところ笳切開創が㗪痕狭窄となっており，そこ で胃弁移植術を追加したところ, 愁訴は改善し術後の $\mathrm{X}$ 線像もバリウム噴門部通過良好となっていた。

以上のごとく胃弁移植術が再手術の方法として有効 な理由は症例に合わせて舌状有茎胃弁を自由な大きさ に取り切開創を補媜することがでさるので確実に通過 障害を取り除くことができるためと考がえている.

再手術を小括してみると次のごとくである。(1)教室 初回の手術例のうち約 $10 \%$ が再手術を受けていた. (2) 教室再手術 30 例のうち $33 \%$ は再々手術を受け, さらに そのらち $40 \%$ が 4 回目の手術を受けていた。 (3)教室初 回手術例で再手術率の高い術式は裂孔拡大剶離術, 食 道胃側々吻合術, 粘膜外筋切開術, 噴門成形術であっ た. (4)再手術を受けた理由は通過障害がほとんどで あった。(5)再手術の術式としては胃弁移植術が最も成 績がよかった。

\section{4. 手術適応}

以上の病態あるいは外科的治療の成績からわれわれ は本症に対する術式の適応として表 8 のごとく考兄 る. 教室では 1965 年以降は病恼期間, $X$ 線像, 内圧分 類などで初期像を示す食道緊張型の症例は粘膜外筋切 開術か胃弁移植術を, 末期像を示す食道扡緩型の症例 には胃弁移植術を適応してきた。ただし今後粘膜外筋 
切開術を行ら場合, 何らかの術後狭窄扎よび逆流の防 止策を追加することを考慮している。

5. 小括

以上，本症の外科的治療をまとめると，まず本症の 病変が進行性であること, 外科的治療は初期像ほど回 復がよいこと,さらに食道癌の合併をb考慮して早い 時期から外科的治療が望ましく, その術式は病態に 沿って適応されるべきである，術式の指針として第 1 に確実に通過障害を除く術式を選択すべきで次いで術 後の狭窄逆流を防止する対策を考える必要がある．各 種術式を行ったが胃弁移植術が最も良い成績であっ た。

\section{考察}

本症に対する治療を行う場合, 本症の食物通過障害 の機序病変の進行の程度を知ることが重要である. 食 物通過障害の機序は食道内圧测定による下部食道接合 部の嬹下時弛緩機序の欠如によるものとされている。 この点以外の付随した本症の病態を種々の方法で検索 したところ, 結論として本症には初期像を呈する食道 緊張型のものと, さらに進んで末期像として食道弛緩 型のものがあると考えられる.この両者には病変進行 があり, 著者の経時的な X 線像の追求で本症には病变 の進行があると考えられた。

外科的治療を行ら場合, この病変の進行程度に応じ た術式の適応，選択が考慮されるべきであろう。

外科的治療であるが，本症の成因，病態が複雑なた め従来より種々の術式が報告されているが, 当然のこ とながら根治手術はない.

外科的治療が最初に行われたのは1897年 Rumpel ${ }^{\text {s) }}$ によってで単純噴門切除術が行われたている。切除法, 狭窄部执張法, 食道成形法, 吻合法, 神経切除法など は最近はほとんど行われていない。

近年行われている最な方法は筋切開法と噴門成形法 である。

笳切開法としては1914年 Heller6)によって行われた 粘膜外筋切開術やその変法" が広く欧米で行われてい る. 噴門成形法は大別して粘膜外筋切開を行ら術式と 全層切開を行ら術式に分けられる. 前者は粘膜外筋切 開術に術後狭窄と逆流を防止する対策を工夫したもの であり ${ }^{8) 9}$, 後者は十分な拡張を得る目的で全層を切除 するとともに括約機構を再建する方法1011)である.

らなみに最近に拈ける欧米の成績をみると，なず粘 膜外筋開術は良好, 軽快を合せ $80 \%$ から $90 \%$ となって いる.これに Fundoplication などのいわゆる逆流防止

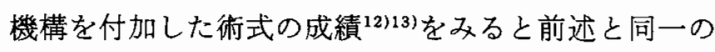
術者が行っていて良好，軽快は一層良くなっている。

本邦においてる本症に対する術式の工夫改良がなさ れている.1980年前後に拈いて改良された噴門成形法 が報告されている，本邦報告の主なる術式と成績をみ ると胃弁移植術 ${ }^{11}$, , Girard 変法 ${ }^{14) 15)}$, Jekler-Lhotka 法 $^{8 / 9)}$, Fundic Patch 法 ${ }^{10)}$, 横隔膜成形術 ${ }^{16)}$ な゙が好成 績を挙げている.

教室ではいくつかの術式を行いその手術成績を比較 したところ, 胃弁移植術が最も良好な成績を挙げたこ とが判明した。 また本症を長期に観察するらちに再手 術を行わねばならない症例子出たが, 教室では30例45 件の再手術を施行した。この最終術式として胃弁移植 術は14例に行われたがいずれる好成績を得ている。 た胃弁移植術を行った104例中再手術を行った症例は ない.

\section{結語}

食道アカラシア444例の病態を食道 X 線, 内王, 筇電 図，内視鏡および䡒液検査で検討した。本症は内圧細 分類による $\mathrm{A}_{1}, \mathrm{~A}_{2}, \mathrm{~A}_{3}$ 型のごとき初期像(食道緊張型) と B 型のごとき末期像（食道弛緩型）がある。本症に は18例 $4.1 \%$ に食道癌の合併をみた.

275例に各種の外科的治療を行ったが胃弁移植術を 施行した104例のうち, 遠隔を追求した97例中良好 91 例，軽快6例と $100 \%$ 改善を得た。教室で施行した 30 例45件のらち再手術の方法として胃弁移植術を14例に 行ったがいずれも好成績であった。

本稿は第29回日本消化器外科学会総会(昭和62年 2 月, 名 古屋)でその主旨を発表した。また稿を終るに臨み御指導を いただいた佐藤 博名誉教授ならびに磯野可一教授に深甚 な謝意を表します。また御協力いたたいた教室各位に厚く 御礼申し上げます。

共同研究者: 原 輝彦, 桜庭康悦, 紅谷 明, 元山逸功, 大宮安紀彦, 遠山政彦, 竜 崇正, 向井 稔, 神津照雄, 山 㱦義和，村島正泰，山本義一

\section{文 献}

1) Willis T: Pharmaceutica rationalis. 1674, cited by Hurst AF : Some disorders of esophagus. JAMA $102: 582-587,1934$

2）佐藤 博, 平島 毅: 有菱胃弁移植下部食道接合 部成形術の理論と実際. 手術 $23: 269-273,1969$

3）食道疾患研究会編：食道アカラシア取扱い規約. 東京, 金原出版, 1984

4）食道疾患研究会編：食道癌取扱い規約. 東京, 金原 出版, 1976

5) Rumpel T: Die klinische diagnose der spindel- 
förmigen Speiseröhrenerweiterung. Munchen Med Wschr $44: 383-386,1897$

6) Heller E: Extramuköse Cardioplastik beim chronischem Cardiospasum mit Dilatation des Oesophagus. Mitteil Grenzgeb Med Chir 27 : 141-149, 1914

7) Ellis FH Jr, Olsen AM, Holman CB: Surgical treatment of cardiospasm (Achalasis of the esophagus). Considerations of aspect of esophagomyotomy. JAMA $166: 29-36,1958$

8) Jekler J, Lhotka J: Modified Heller procedure to prevent postoperative reflux esophagitis in patients with achalasia. Am J Surg 113 : 251-254, 1967

9）内山八郎, 加治佐隆：いわゆる特発性食道抾張症 に対する手術々式一Heller 内山変法 Esophagofundopexykついて. 外科治療 10 : 335-337, 1968

10）篗福哲彦, 日下純男, 八島良幸注：食道アカラシ
フに対する Fundic patch 法の理論的根拠と手術 成績. 日消外会誌 $8: 72-79,1975$

11）平嶋 毅：食道厂カラシフの外科撩法一胃弁移植 術の遠隔成績一. 日消外会誌 $8: 81-85,1975$

12) Donahue PE, Schlesinger PK, Bombeck CT et al : Achulasia of the esophagus, treatment, controversies and the method of choice. Ann Surg 203 : 505-51.1, 1986

13) Pai GP, Ellision RG, Rubin JW et al: Two decades of experience with modified Heller's myotomy for achalasia. Ann Thor Surg 38, 201-206, 1984

14）田中 隆：Girard 変法による食道アカラシフの 手術. 手術 $40: 1567-1574,1986$

15）井手博子, 遠藤光夫, 木下裕宏汪か：食道アカラシ 了に対するGirard変法. 日胸外会誌 29 ： 556-558, 1981

16) Petrovsky BV: Cardiospasm and its surgical correction. Ann Surg $155: 60-71,1962$ 